\title{
René Metras, un hombre de nuestro tiempo. Galeria René Metras y la vanguardia estética en Barcelona
}

\author{
María del Carmen Briones Brú
}

\section{René Metras, a man of our time. René Metras gallery and the esthetic avantgarde in Barcelona}

\begin{abstract}
RESUMEN
El propósito de este trabajo es reconocer $y$ poner de relieve la figura, no siempre reconocida en los medios artísticos actuales de un hombre, René Metras.
\end{abstract}

Vinculado desde los años cuarenta a movimientos artísticos catalanes de posguerra, participó con los intelectuales y jóvenes artistas catalanes, con su esfuerzo, ímpetu y dedicación personal, siendo una figura muy significativa en los primeros momentos de las vanguardias del arte español de los años 50 y 60. En octubre de 1962 abre las puertas de la galería que lleva su nombre, en la calle

Consejo de Ciento, 331 de Barcelona alentado por la idea de mostrar al público barcelonés un arte distinto e innovador al que se mostraba en la mayoría de las galerías de arte. Pionero en mostrar lo que pasaba fuera de nuestro país, desde su inauguración apostó por las vanguardias europeas $y$, en sus salas, pudo verse por primera vez a los grandes artistas del siglo XX; promovió, fiel a su ideario, a jóvenes y relevantes artistas catalanes y del resto de la Península, defendiendo con pureza y rigor el arte abstracto e informalista. René Metras no sólo abrió sus puertas a Barcelona, también abrió Barcelona al mundo artístico internacional, siendo su galería un referente mundial de la vanguardia estética de Barcelona.»

\section{ABSTRACT}

The purpose of this work is to recognize and highlight the figure, not always recognized in the current artistic means of a man, René Metras.

Linked from the forties to Catalan postwar art movements, he participated with intellectuals and young catalan artists, with effort, dedication and personal commitment, being a figure very significant in the first moments of Spanish art vanguards in the fifties and sixties. In October 1962, he opened the doors of the gallery bears his name in Consell de Cent street number 331 in Barcelona, encouraged by the idea of showing to the Barcelona public a more innovative art than sown in most art galleries. A pioneer in showing what was happening outside our country, since its opening bet on the European vanguardists, he saw for the first time in his rooms the great artists of the twentieth century; promoted, true his ideals, youth and relevant Catalan artists and the rest of the Peninsula, defending with purity and rigor informalist abstract art. René Metras not only opened its doors to Barcelona, he also opened Barcelona to the international art, being its gallery a world leader in the asthetic vanguard of Barcelona. 


\section{PALABRAS CLAVE KEY WORDS}

Metras, informalismo, arte abstracto, galería de arte

Metras, informalism, abstract art, art gallery

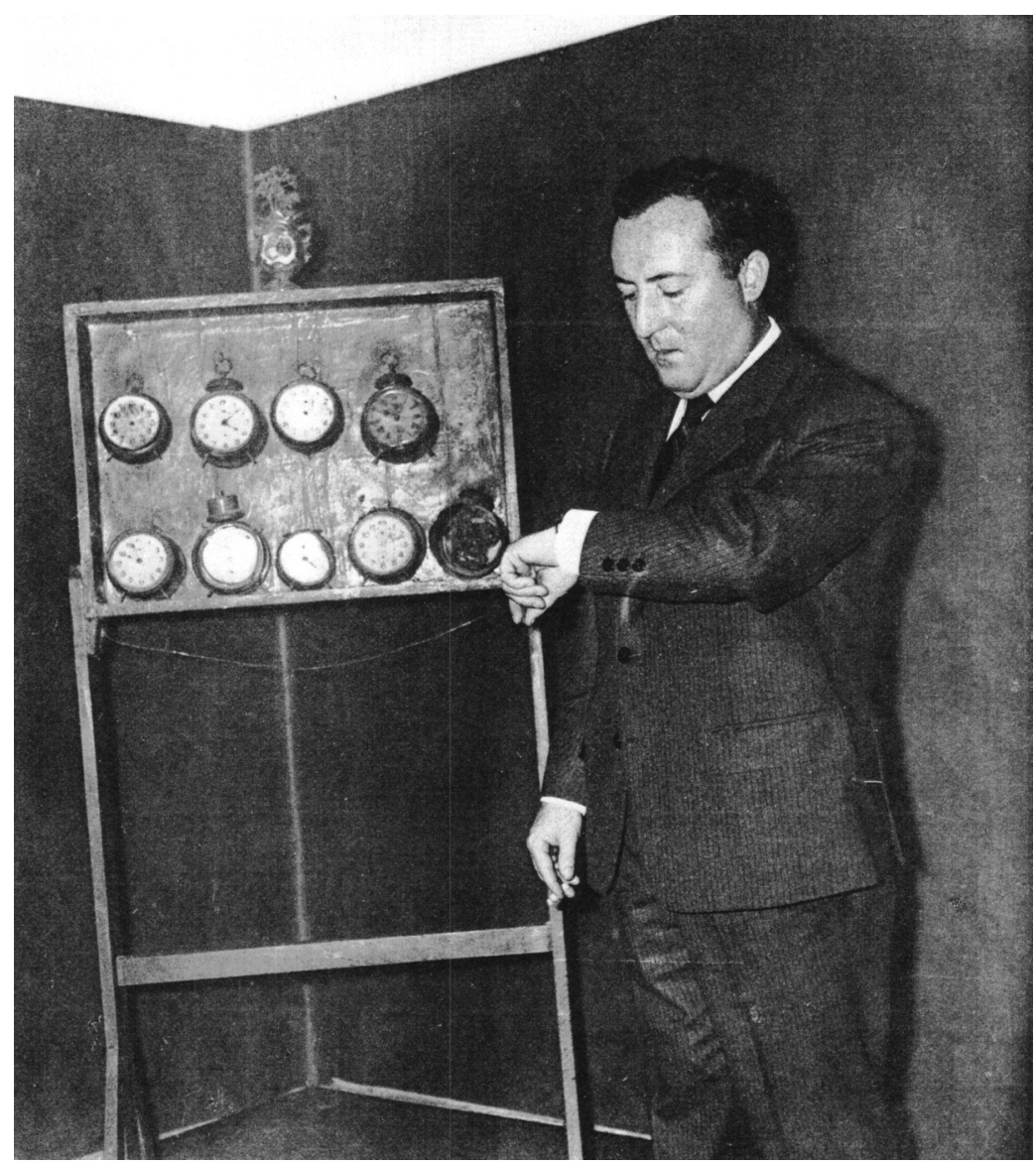

Fig. 1. René Metras, esperando el momento de abrir la Galería René Metras. Relojes con diferentes bandas horarias simbolizan la intención de su propietario de abrir la galería al mundo artístico internacional.

«No para sugestionar, pero sí para dar la posibilidad de un mejor conocimiento del arte actual surge esta galería, en la que esperamos dar muestra de las tenencias más interesantes de la vanguardia estética. Nuestra aspiración, que podrá ser limitada en mayor o menor grado por las circunstancias, es la de no reducirnos exclusivamente al panorama nacional. Lo fecundo de los contactos, lo valioso de las comparaciones, habrá de ser ratificado una vez más y esperamos que sea nuestra sala una de las que mejor contribuyan a este resultado». René Metras, octubre de 1962. 
René Metras, un hombre de nuestro tiempo. Galeria René Metras y la vanguardia ...

Con estas palabras René Metras, en octubre de 1962, abría las puertas de la galería que lleva su nombre en la calle Consejo de Ciento, 331 de Barcelona y que se inauguró con la exposición: «Presencias 1945-1962»1.

René Metras, era un ciudadano francés, que se sentía muy catalán, mediterráneo, culto, polifacético y buen conocedor de las nuevas tendencias plásticas que se estaban practicando, en ese momento, fuera de nuestras fronteras.

René Metras Mavet, nació en 1926 en Saint Etienne, Francia, en el seno de una familia de ingenieros textiles especializados en seda. En 1942, su padre, Charles Metras Wagner, logra entrar en España; compra una casa en Sant Celoni y abrirá su propia fábrica textil en el barrio de Pueblo Nuevo de Barcelona.

Cuando llega a Cataluña, en plena Dictadura franquista, se encuentra con un panorama artístico barcelonés, en el que escaseaban los artistas (muchos de ellos, hubieron de exiliarse al acabar la guerra) y los que quedadan, la mayoría seguía practicando un arte novechentista, a todas luces anticuado. Afortunadamente, también había otros artistas que intentaban cambiar el panorama artístico, a pesar de las trabas de las principales autoridades culturales que rechazaban toda innovación artística de vanguardia, y cuyo principal referente era Francia y Estados Unidos.

René Metras, tras terminar sus estudios en las Escuelas Francesas, Estudiará en la Escuela Superior de Ingenieros de Terrasa, licenciándose en química.

El joven René pasa los veranos en Sant Celoni, en los cuales conoce y trata amistad con los artista Modest Cuixart, Antoni Tàpies y Luis $\mathrm{M}^{\mathrm{a}}$ Riera, que fue reafirmándose, día a día debido al gusto que procesaban por la pintura. Juntos practican la pintura, pero llegó a la conclusión de que se trataba de simples recreaciones sin ningún interés. A los veinte años realizaron un viaje a París, donde conocen la obra de Braque, Paul Klee, Kandinsky.

Pronto se hacen inseparables y se dan cuenta de que les une una gran pasión por la música, el cine y toda actividad relacionada con el arte contemporáneo rompedor que se está produciendo fuera de España y de la que tienen conocimiento a través de los libros y viajes.

Hombre inquieto y muy vinculado a las vanguardias europeas, formará parte de esos intelectuales que intentan que Barcelona recobre su identidad y se ponga a la cabeza de las vanguardias en una España asfixiante y gazmoña.

Son los años de la autarquía y pobreza artística en los que se halla inmersa España y, en los cuales, el panorama del arte moderno era desolador; todo ello

${ }^{1}$ Catálogo de la inauguración de la galería 1962 : Artistas: J.B.Chereau, Javier Corbero, Modest Cuixart, Hernández Pijuán, Jean Fautrier, Luis Feito. 
agravado en $1946^{2}$ por la retirada de embajadores extranjeros y que afianzaron en sus posturas a los enemigos de la apertura en nuestro país.

Tras terminar sus estudios en las escuelas francesas, estudiará en la Escuela Superior de Ingenieros de Terrassa (Barcelona) licienciandose en química. En 1947 empieza a trabajar en la fábrica de su padre como colorista pero ese trabajo, para el que había estado preparándose no acaba de llenarle y, a la muerte de su padre, inicia su aventura dentro del mundo del arte al que se dedicará en cuerpo y alma durante toda su vida.

René y sus amigos ávidos de saber todo lo que está pasando más allá de los Pirineos, proponen reunirse, periódicamente, en la Plaza Molina de Barcelona, para hablar de arte y las novedades científicas que se están produciendo en el extranjero. Pronto serán asiduos de estos encuentros Joan Brossa, Joan Ponç, J.Mª Tharrats y más tarde a Arnau Puig, Juan Eduardo Cirlot y otros.

Fruto de esas tertulias culturales, en el mes de septiembre de 1948 se publicó el primer número de la revista Dau at Set $^{3}$, cuya aparición estuvo ligada a la convocatoria del Primer Salón de Octubre de ese mismo año, y cuyo precedente había sido Argol ${ }^{4}$.

En Barcelona, el grupo Dau al Set, reflejaba la ideología de los miembros del grupo, entre dadaísta y surrealista-magicista (especialmente tenían como referente a Joan Miró); la verdad es que se trataba de personalidades muy diversas que acabó dispersando el grupo, e independizándose después de su exposición en la Sala Caralt de Barcelona del 6 al 19 de octubre de 1951, en la cual, expusieron obra suyas y se mostró una proyección de lo realizado hasta entonces. Años más tarde reconocería Antoni Tápies:

«(...) Aquel grupito fue una unión que duró poco, porque, aparte de la simpatía natural que yo experimentaba por Brossa, y también por Arnau Puig, con los otros tenía pocas afinidades, e incluso nos separaban puntos de vista totalmente antagónicos. De hecho, sólo seguí viendo a Brossa con regularidad durante años. Creo que los números de interés de Dau al Set estaban hechos bajo la influencia directa de nuestro amigo poeta, que en aquel momento fue decisiva -y que en ocasiones incluso nos inclinaba excesivamente hacia las imágenes literarias- en los pintores del pequeño gru-

\footnotetext{
${ }^{2}$ La Asamblea General de la ONU, el doce de diciembre de 1946, recomienda la no-admisión del Régimen de Franco en su organización, y en los organismos dependientes de ésta, por su alineación profascista durante la Segunda Guerra Mundial.

${ }^{3}$ Fundada por los pintores Joan JosepTharrats, Antoni Tápies, Modest Cuixart y Joan Ponç, el poeta Joan Brossa y el filósofo Arnau Puig y más tarde se les unirá el poeta y crítico de Arte Juan Eduardo Cirlot, y el grabador Enric Tormo. Colaboradores asiduos fueron Sebastiá Gasch, Rafael Santos Torroella, Ricardo Gullón, Mathías Goeritz , entre otros.

${ }^{4}$ Argol aparece en 1947, impresa por Enrique Tormo, escrita en catalán cuenta con las colaboraciones de Joan Ponç, Joan Brossa, Jordi Mercadé, Arnau Puig y Francisco Boadella, de la que sólo se editará un número, que como afirmaba Santos Torroella, había sido considerada la primera revista con vocación vanguardista editada después de la Guerra Civil.

${ }^{5}$ Memoria Personal. Fragment per a una autobiografía. Tapies, Antoni. Editorial Seix Barral 1977.
} 
René Metras, un hombre de nuestro tiempo. Galeria René Metras y la vanguardia ...

po; especialmente sobre Ponç, a quien recuerdo como iniciado en el automatismo y el cual, más tarde, hizo verdaderas ilustraciones de sus poemas» ${ }^{5}$.

Dau al Set fue mucho más que una revista. Fue la obra de un reducido grupo de pintores y escritores que se oponen al anquilosamiento cultural que, en su época, constituyen una radical e inteligente oposición al inmovilismo y conformismo que por entonces presionaba con rigor en los ambientes artísticos y culturales. Así lo demuestra los homenajes a Paul Klee, Joan Miró, René Magritte, Max Ernst, Antoni Gaudí, Arnold Schönberg, Luis Amstrong, Francis Picabía, entre otros.

Sin lugar a dudas, con esta revista se ponían los cimientos de una vanguardia, en la posguerra de una Cataluña vencida y humillada, que pugnaba por expresarse en otro lenguaje artístico, como el que se estaba haciendo en el extranjero, abriendo una brecha de inconformismo contra el arte oficial y academicista defendido por el Régimen franquista.

En 1949 se produce otro acontecimiento que tendrá gran importancia en la recuperación cultural y artística catalana, como es la constitución del grupo Club 49.

René Metras, que había participado en Dau al Set como tesorero de la revista, y junto con Joan Prats ambos coleccionistas compró varias obras de los jóvenes pintores integrantes del mismo conviertiéndose en su promotor y animador. Estuvo en contacto permanente con los grupos de Hot Club ${ }^{6}$ y el Club 497. En los años 50, sería la institución catalana más dinámica e imaginativa de promoción del arte nuevo.

El Club 49, aglutinará a los colaboradores más radicales de la revista Cobalto ${ }^{8}$ y que habían tenido como referente las actividades realizadas en el pasado en Adlan y Gatcpac y representaría, durante estos años, la continuidad de la vanguardia artística catalana de entreguerras en un momento difícil, de represión cultural y aislamiento.

En 1950, Metras conoce la vanguardia parisina y europea al entrar en contacto con los marchantes parisinos René Drouin y Michele Controurier que le muestran la obra de Jean Dubuffet, Jean Fautrier, Hans Hartung. Alfred Wols, Piero Manzoni y Lucio Fontana con los que tendrá una excelente relación y expondrá, con posterioridad, en su galeria.

René Metras, desde sus primeros contactos en Sant Celoni con los jóvenes pintores Tàpies y Cuixart comprendió que su papel no era el de ser artista. A los 17

\footnotetext{
${ }^{6}$ Organizaba Salones de Jazz y otras actividades artística innovadoras. El primer Salón de Jazz se celebró en 1951; el segundo en 1952; el tercero en las Galerías Layetanas y el cuarto en 1957, todos ellos con la participación y colaboración de los artistas más representativos de la vanguardia de entonces.

${ }^{7}$ Se constituyó inicialmente como una sección del Hot Club de Barcelona para conseguir una cobertura legal para sus actividades. La Junta estuvo integrada por Sixto Illescas, como Presidente; Pedro Casadevall, vicepresidente; Joan Prat, secretario; y, como vocales: Sebastián Gasch, Joaquín Gomas, Eudaldo Serra y Javier Vidal de Llobatera.

${ }^{8}$ Agrupación fundada en Barcelona el 28 de abril de 1949 por S.Gasch, Joaquim Gomis, S.Illescas, Joan Prats y Eudald Serra (procedentes de ADLAN), y Maria Teresa Bermejo y R.Santos Torroella (de la revista de arte Cobalto, 1947-48, que dará nombre al grupo).
} 
años empezó a coleccionar dentro de sus posibilidades económicas. Su fino olfato para las nuevas tendencias le llevó a comprar, obras de sus mejores amigos y artistas teniendo una vasta colección que ocupaba todas las paredes de su casa llegando a ser considerado un joven cosmopolita que coleccionaba (en unos años en que el coleccionismo en España era reducidísimo) una pintura extravagante y que, por supuesto, no consideraban arte. Román Vallés ${ }^{9}$ recordando años más tarde una visita al piso de Metras decía:

(...) Para comprender mi asombro, el lector debería situarse un poco en el ambiente artístico de nuestra ciudad por aquellos tristes días. En muchos aspectos, el desgraciado aire de la posguerra era todavía vigente. Seguía siendo muy difícil salir al extranjero, la falta de información sobre las vanguardias de antes y después de la segunda guerra mundial era absoluta, el gusto del público en general seguía enquistado en las formalistas exposiciones que durante los años cuarenta habían logrado formar interminables exposiciones que durante los años cuarenta habían logrado formar interminables colas en las Galerías correspondientes. Oficialmente imperaban los dogmas de la Escuela de Bellas Artes, una Escuela Superior que se erigió independiente de la Longa pocos años antes y ofrecía sólo un mediocre academicismo.

Descubrir en este ambiente a alguien que sólo hablaba de Fautrier, Mathieu, Chereau, Miró o Picasso, además de otros muchos desconocidos que luego han sido los nombres que han formado la gran pléyade de artistas de la posguerra, y ver como aquel hombre bajito, afable, de mirada entre escrutadora y burlona, que hablaba medio catalán medio francés se desmelenaba para adquirir unas obras que nadie, por aquel entonces, hubiese aceptado ni regaladas, fue para mi una gran revelación ${ }^{10}$.

En 1957 comienza su labor como marchante. Edita y financia la revista Correo de las Artes publicación única de estas características que se hace en esa época. Se diferencia de la revista Dau al Set en que aquella era hecha por los propios artistas del grupo de una forma prácticamente artesanal, algo elitista, endogámica y,

\footnotetext{
${ }^{9}$ (...) L'obra de Romà Vallès neix de les entranyes del més pur informalisme, a meitat del anys cinquanta, quan manté un estret contacte amb les avantguardes artístiques a París, convertint-se en un dels precursors més implicats d'aquest moviment a Catalunya. Des d'aleshores, l'artista aprofundeix en l'abstracció més ferotge i manté un pols constant amb la investigació i la creació plàstica. No és d'estranyar que la seva obra s'hagi mantingut ferma en els seus principis més essencials, nodrint un corpus que ha passat per diferents etapes, i en les quals el tractament de cadascuna ha incidit en noves aportacions vers la matèria, l'espai, el gest i el color. Moltes han estat les etapes que s'han materialitzat en diverses sèries, concretament onze fins ara: des de la primera anomenada Cosmogonies, fins a l'última titulada Heràclit, a través de les quals ha demostrat en tot moment la vinculació de les seves inquietuds personals amb les experiències pictòriques. Des de l'informalisme, del qual és un dels màxims representants, fins al nou realisme, passant per l'espacialisme, el procés de reflexió conceptual o el lirisme de la pintura més vital, sens dubte, la seva obra ha recollit el sentiment, les experiències i les preocupacions de cadascuna de les èpoques per les quals ha transcorregut. Valorant globalment la seva densa trajectòria portada a terme, constatem l'existència d'un fil conductor que s'estableix com a eix vertebrador de tot el seu discurs. Són, especialment, el traç i la taca, complementant-se amb la matèria i el color, els elements definidors del seu llenguatge que suggereix tants espais microscòpics com macrocòsmics, en mirades obertes d'infinites lectures. Text de Joan Gil, historiador i crític d'art. Romàn Vallès (1923) Ricard Planas, director de la revista Bonart, entrevista Romà Vallès al seu estudi de Barcelona.Sies.TV

10 Vallés, Roman. Pintor. En torno al coleccionismo barcelonés: René Metras. René Metras 1926.1984: Reconstruir los sueños. Ambit Servicios Editoriales. 2008.
} 


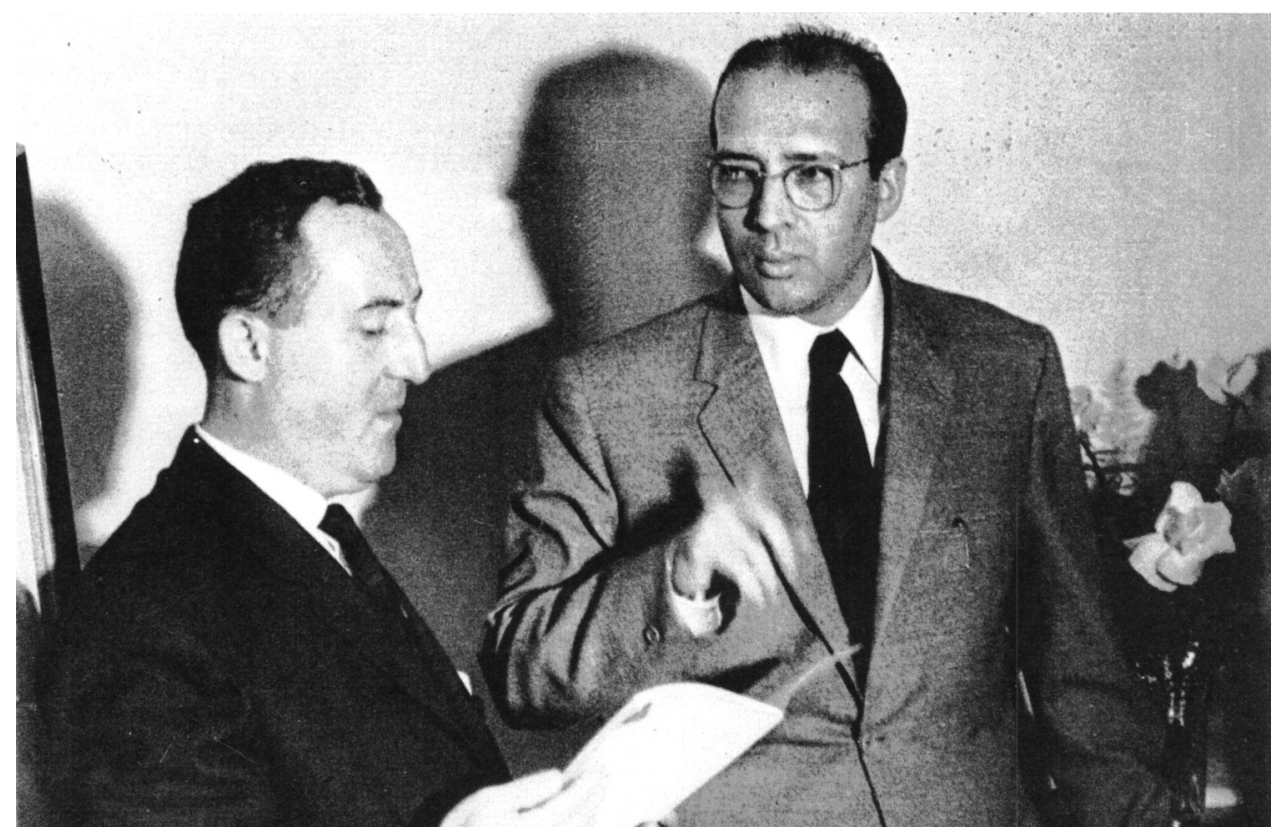

Fig.2: René Metras (izquierda) y Juan Eduardo Cirlot

esta otra, pretende ser una revista de arte de carácter internacional y abierta a un lector más heterogéneo.

Metras se embarca en esta aventura con entusiasmo. Asumirá la dirección artística de la revista y contará, entre otros, con la estrecha colaboración de Juan Eduardo Cirlot ${ }^{11}$ cuyos artículos, son testimonio de una diferente, particular y novísima forma de hacer crítica y defensa de ese Arte Otro donde los jóvenes artistas plasman en las telas su disconformidad. Ambos planifican la revista y mantenían largos diálogos sobre el arte de Vanguardia. Cuentan con colaboradores diversos en Madrid y el extranjero. La revista deja de publicarse en 1962 a causa de diversos problemas financieros.

Revisada esta revista hoy puede verse la ilusión, rebeldía y esfuerzo realizado para llevarla adelante y uno se sorprende leyendo unos magníficos artículos que a

\footnotetext{
${ }^{11}$ Testigo de excepción y copartícipe durante los años cuarenta, cincuenta y sesenta de la fundación y desarrollo de principales movimientos de renovación y vanguardia en el campo del arte español, escribe y firma manifiestos, publica innumerables artículos en revistas nacionales e internacionales, así como diversas monografías y libros de arte y sobre artistas, siendo en nuestro país uno de los principales especialistas en la particular poética y estética del surrealismo, y es considerado, asimismo, como el primer y más incisivo y agudo teórico y exégeta de la abstracción informalista catalana y nacional. Francisco Guinea, Chema de: El mundo de Juan-Eduardo Cirlot. Breve Crónica de una recuperación. Exposición en el Centro Julio González del Instituto Valenciano de Arte Moderno. 19 de septiembre de 1996.
} 


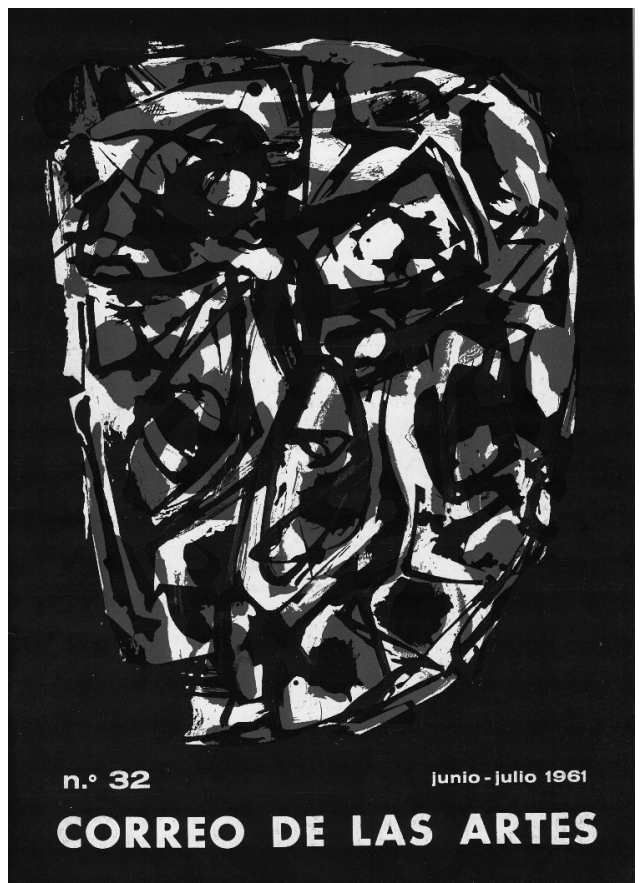

Fig.3:: Portada de la revista Amigos de las Artes, $n^{\circ}$ 32, año 19XX

pesar del cerco al que se sometía a toda actividad social y artística, consigue burlar los diques de la censura.

Correo de las Artes se publicó durante los años 1958 al 1962. El 23 de febrero de 1957 saldrá el primer número. Tras el saludo, se expone cual va a ser el ideario de la misma, y lo que podemos encontrar en sus páginas ${ }^{12}$. Así, en la primera página vemos convenientemente destacado: «Picasso, Joan Miró y Llorens Artigas decorarán el Palacio de la UNESCO en Paris. A Picasso le ha sido confiado el Salón de Sesiones, y al ceramista Llorens Artigas, en colaboración con Joan Miró, dos muros cuyas medidas son 15 metros de ancho por 3 de alto, el primero y 7 por 3, el segundo. El americano Calder, tendrá a su cargo las esculturas móviles, el francés Arp, los apliques, Moore, el escultor inglés, las esculturas, y el japonés Noguchi tiene a su cargo los jardines. Y DALI ... ¿qué?». También, en la misma página hay un articulo titulado el «Arte Otro» de Juan Eduardo Cirlot acompañado de

12 «Nuestro Saludo: Un saludo cordial, ancho y sincero, es el que dirigimos desde las columnas de este primer número. No se nos oculta que a la par que nuestra aparición surge para nosotros una delicada responsabilidad de honradez hacia las puras, las honradas manifestaciones artísticas que se han hecho merecedoras de colaboración e incluso de ayuda. "Correo de las Artes» sale a la calle libre de prejuicios y con sano espíritu de comprensión. Por consecuencia, no se adhiere a ningún grupo, ni pretende obedecer tendencia alguna determinada, Ahora bien, queremos y debemos proclamar que partimos en busca de renovadas emociones estéticas, que nos interesa profundamente el futuro del Arte...». Correo de las Artes. Núm. 1. Barcelona 23 de febrero de 1957. 


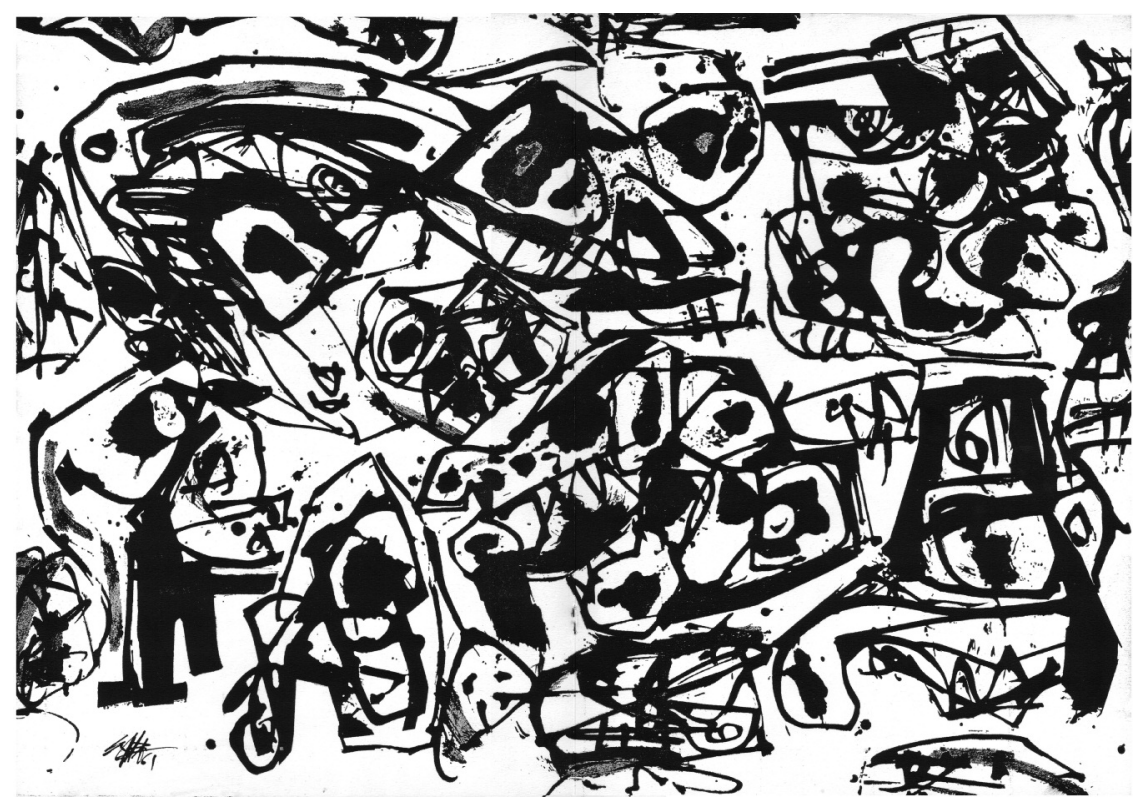

Fig.4: Desplegable serie «Multitudes».Antonio Saura

una fotografía de una pintura de Jean-Paul Riopelle ${ }^{13}$, como muestra inequívoca de lo que pretende ser la revista. Más tarde, en la Tercera época de la Revista, en su núm. 32, correspondiente a junio-julio de $1961^{14}$, se incluye un dibujo realizado por Antonio Saura de la serie «Multitudes» ${ }^{15}$.

En los años sesenta comenzarán a verse los primeros resultados de las medidas económicas liberalizadoras como resultado de la puesta en marcha del Plan de Estabilización Económica en 1959.

Dentro de esta nueva ordenación tendrá un peso especial, por un lado, la importante tasa de emigración de los españoles que durante los años 60 y 70 proveerá el sector industrial europeo en expansión después de la Segunda Guerra Mundial (especialmente Alemania, Francia, Suiza y Bélgica) de mano de obra y, por otro lado, el hecho de que esta misma Europa en expansión, llegará a nuestro país de forma masiva en calidad de turismo, ávido de sol y playa y que ocupará principalmente la franja costera, contribuyendo, con su presencia, a incrementar el censo de sus poblaciones, lo que contribuirá al desarrollo en las mismas durante los meses de verano

${ }^{13}$ Pintor, escultor y artista gráfico canadiense. Está considerado como el principal pintor abstracto canadiense de su generación, aunque desde 1947 ha residido en París.

${ }^{14}$ Colaboran en este número: Carlos Antonio Arean, Sebastián Benet, Juan Eduardo Cirlot, Jean Dypreau, Marcel Fryns, Luís de Lázaro Uriarte, Angel Marsa, René P. Metras, Mercedes Molleda, Danielle Pampuzac, José Vallés Rovira, J.B.Martí y Carbonell.

${ }^{15}$ Realizado por Antonio Saura especialmente para este número 
y a una modificación progresiva urbanística y geográfica del territorio. El ingreso de divisas de los emigrantes, el derivado de la afluencia de turistas y la inversión de capitales extranjeros, generado por la inversión inmobiliaria, serán decisivos en el relanzamiento económico de estos años, que contribuirán a modernizar los diferentes sectores productivos -industrial, construcción y servicios-.

Los cambios económicos aumentarán el poder adquisitivo de una importante parte de la población, que demanda bienes de consumo y que ayudará a acelerar la dinámica productiva. Pero en estos años, además de producirse el progreso económico, también se produce una apertura al exterior, lo que provoca conflictos, pues se toma conciencia de la falta de libertades democráticas dentro del país. La sociedad en estos años sesenta intenta recuperar la vitalidad perdida.

Serán años donde se producirán las primeras reivindicaciones obreras y estudiantiles que preparan el camino para los cambios decisivos que tendrán lugar en la década siguiente, influyendo todo ello, como no podía de ser de otra forma, en los artistas, que buscan nuevos cauces para desarrollar sus actividades artísticas y que encontrarán en las galerías de arte la respuesta a sus inquietudes.

Es en esta época cuando Metras decide inaugurar la galería que lleva su nombre: Galería René Metras. Este es un proyecto callado que le acompaña desde hace años y que tras una laboriosa preparación y no pocas dificultades logra llevar a cabo.

En octubre de 1962, en la calle Consejo de Ciento 331, bajo el impulso inicial de su fundador (y con la inestimable ayuda de su esposa $\mathrm{M}^{\mathrm{a}}$ Teresa), abre las puertas de su modernísima galería con unas ideas muy claras sobre cuál va a ser la premisa de la misma: acercar al público de Barcelona unas obras y unos artistas, que eran, en sí mismos un manifiesto de su arte.

La nueva galería incidirá de manera importante en el ámbito artístico catalán a través de una larga trayectoria de alto nivel cualitativo, de acuerdo con unos planteamientos integradores, plenamente comprometidos con el arte de vanguardia, tal y como era la voluntad de su fundador y que expondría en el acto inaugural de la galería. René Metras, apostará, desde el primer momento, por el arte de vanguardia y lo hará a través de exposiciones en las que compaginará el arte español con el de producción extranjera, con el objeto de conseguir una visión lo más amplia posible del arte que se está realizando en el mundo. Bajo el nombre genérico «Presencias de nuestro tiempo», la galería pretendía exponer tanto la obra de artistas ya consagrados como la de los más emergentes.

Pero no todo fue sencillo. Cuando se inauguró la galería, el crítico del diario La Vanguardia Juan Cortés ${ }^{16}$ comentaba con cierta reticencia e intencionalidad: «Una nueva sala de arte ha sido inaugurada en Barcelona. Una sala dedicada solamente al comercio de producciones artísticas...» y prosigue: «(...) La exposición con que

\footnotetext{
${ }^{16}$ Juan Cortés. «Presencia 1945-1962»La Vanguardia, 20 de diciembre de 1962, pag.23
} 


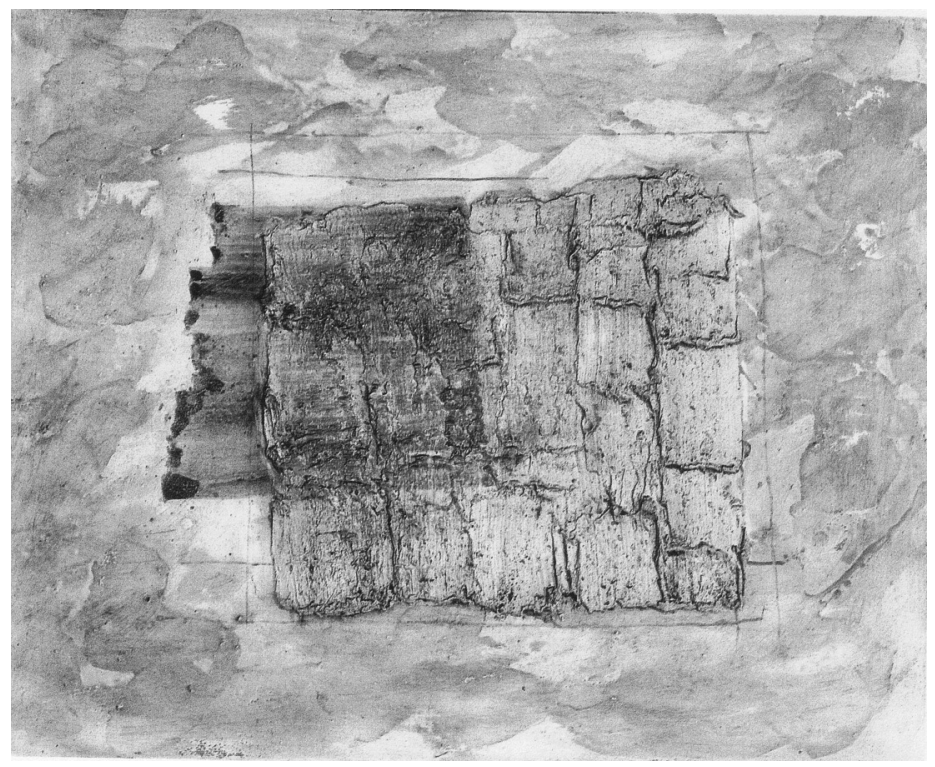

Fig.5: Jean Fautrier. «Indigo et jaune» 1957.Técnica mixta s/tela $60 \times 73 \mathrm{~cm}$.

la «Galería René Metras» ha inaugurado su actuación se titula significativa y exageradamente «Presencia 1945-1962»-excesiva, aunque excusable a título de propaganda». No es de extrañar que, en Barcelona, esta galería produjera efectos desestabilizadores al decantar sus exposiciones por el Arte Nuevo, que aspiraba a cambiar el gusto de la joven burguesía, nada menos. Además, René Metras, pretendía crear un clima artístico actual y europeo, acorde con la sobria expresividad de su galería.

La propuesta de Metras en un tiempo enrarecido por las «manifestaciones de un realismo historicista y de consignas de catecismo radical», sorprendió por su osadía, ya que pretendía revisar el arte a partir de obras muy concretas; mostrar la forma contra la imagen -el llamado arte informal- mostrado frente a frente, exigiendo al observador su participación, dejándose llevar por el mensaje que el artista le dirigía directamente a sus entrañas.

Dentro de estas propuestas cabe destacar la que tendría lugar en julio de 1963. Metras presentó en Barcelona la primera exposición antológica de Jean Fautrier. Santos Torroella ${ }^{17}$ dice en la sección de arte Dietario artístico del periódico Noticiero Universal:: «Un solitario: Jean Fautrier. Un pintor que tiene adversarios a muchos pintores, y por admiradores a la mayoría de los poetas», ha dicho André Malraux de Fautrier» (...) «En la pintura de Fautrier advertimos siempre, sugeren-

\footnotetext{
${ }^{17}$ Un solitario:Jean Fautrier. Santos Torroella. El Noticiario Universal, diario de la tarde, 3 de julio de 1963
} 
cias, alusiones concretas a algo -que los títulos, por otra parte nos ayudan a verbien de modo vago, con una amplitud de la que sólo emergen algunas misteriosas, poéticas vibraciones de las imágenes que así se nos suscitan». Y Juan Perucho $^{18}$ en su crítica diría: (...) ¿Quién es Fautrier? Hemos dicho hace un momento que es el fundador, o uno de los fundadores, de la pintura más joven de nuestro tiempo, o sea el Informalismo". Jean Fautrier, era un clásico, un batallador incansable y el portavoz del Informalismo. Pero sería un joven crítico, Francesc Miralles, quien entendiera en su apreciación justa la pintura de Fautrier y el protagonismo de la materia, origen del Informalismo: «una pintura inerte en la que la materia lo es todo y así lo comprendieron Tàpies, Cuixart y Tharrats en Barcelona o Canogar y Millares en Madrid». ${ }^{19}$

Durante la década de los sesenta se realizarán varias exposiciones individuales entre la que cabe destacar, entre otras la de Modesto Cuixart en Abril-Mayo de 1963 de la cual A.del Castillo ${ }^{20}$ en su artículo "Cuixart en Galería René Metras» dice:

«Para muchos la de Cuixart es una exposición de escándalo. Algo hay de eso, es indudable. De ahí que abunden los que la visitan ávidos de truculencias.

(...) Insiste, una y otra vez, en la introducción de objetos en sus cuadros, impulsado por vientos surrealistas y dadaístas y, sobre todo por su deseo de abjurar del Informalismo, al que considera caducado y hoy fuera de lugar. Es evidente que existe una coincidencia entre esta postura y la de otros artistas, particularmente norteamericanos»

Y el crítico F. Gutierrez ${ }^{21}$, en su artículo publicado con motivo de esta exposición señala:

(...) Sobrecogen esas pinturas, en las que se inicia una «neofiguración» a través de sus «collages» desoladoramente trágicos. El universo informalista se destruye a sí mismo en un esfuerzo titánico y angustioso, pero la poesía subsiste»

Esta exposición llegará a ser polémica, ya que el escultor $\mathrm{C}$. Sansegundo, reclamará para sí la paternidad de las muñecas y acusa a Cuixart de plagio, como recoge en su artículo Angel Marsá22 .

Cuixart volverá a exponer en la Galería René Metras del 13 de abril al 16 de mayo de 1966, siendo la misma, de gran interés para la prensa. Juan Gich ${ }^{23}$ dice:

(...) Lo primero que destaca en esta exposición es el rejuvenecimiento que se observa en Cuixart. Sí, rejuvenecimiento. Como si hubiera tomado una de esas pó-

\footnotetext{
${ }^{18}$ Juan Perucho: Invención y criterio de las Artes: La Pintura de Jean Fautrier. Diario Destino, Barcelona, 6 de Julio de 1963-№ 1352.

${ }^{19}$ René Metras 1926-1984. Reconstruir los sueños.J.E. Yvars. Ambit Servicios editoriales.2008.

${ }^{20}$ A. Del Castillo. Cuixart, en Galería René Metras. Diario de Barcelona, sábado, 27 de abril de 1963

${ }^{21}$ F. Gutierrez. Modesto Cuixart, en Galería René Metrá. La Prensa, 23 de abril de 1963.

${ }^{22}$ Angel Marsa. La paternidad de las muñecas. El Correo. Barcelona, Domingo, 26 de mayo de 1963.
} 


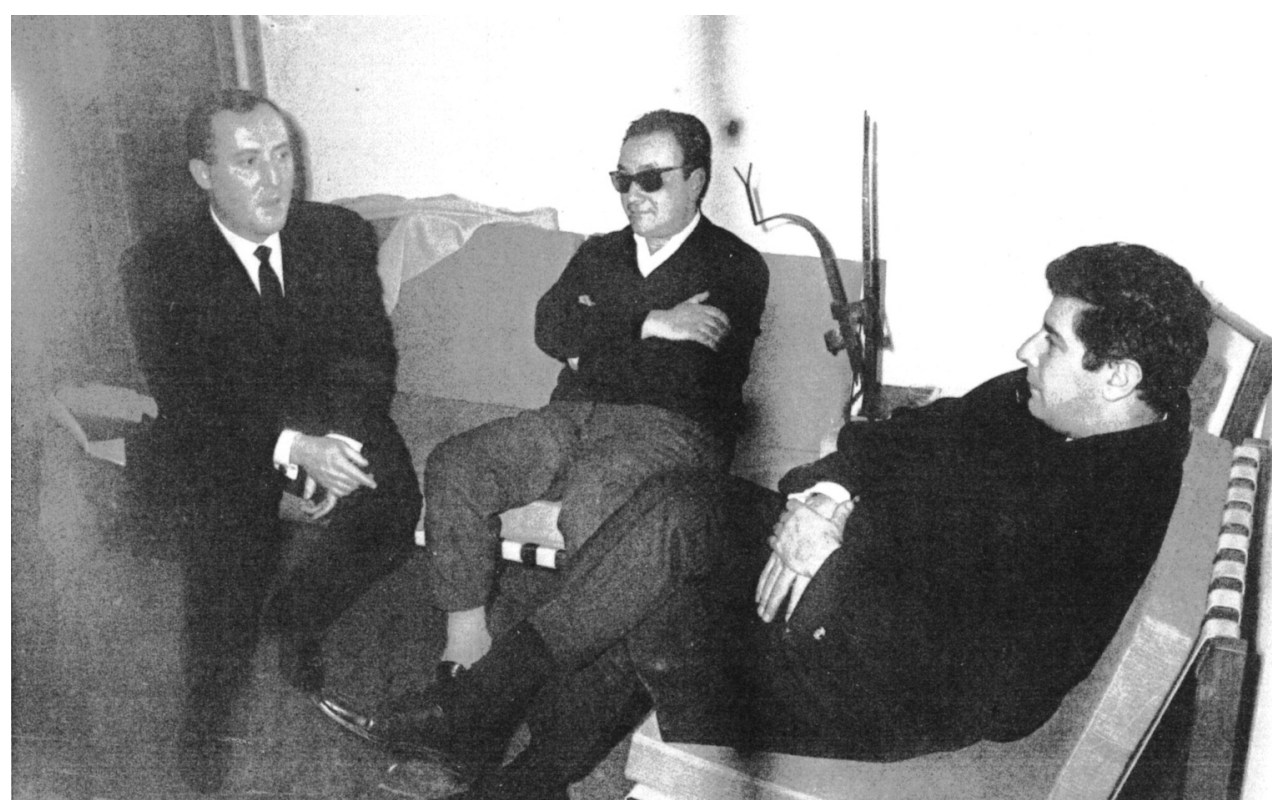

Fig.6: René Metrás, a la izquierda de la foto, parece escuchar atentamente a Cuixart, a la derecha de foto. En el centro Joan Brossa.

cimas o recetas -cuyos secretos sólo conoce Joan Perucho- Cuixart ha dado un salto de veinte años»

Y Ángel Marsá: ${ }^{24}$

«La pintura de Modesto Cuixart, el gran inquieto, ha sufrido una nueva transformación.

(...) De su magicismo inicial, de su etapa informalista, sus texturas erosionadas, sus «collages» y su «Pop-Art» consecutivos, pasa a esa nueva figuración...»

Carlos Carrero en su apartado «Así es la gente» recoge la entrevista realizada a Cuixart en la inauguración:

«(..) - ¿Cómo es que después del «pop-Art.» de las muñecas no ha seguido con el «pop-art?»

- Yo nunca he hecho ni «pop» ni «op». Protesto contra esas etiquetas. Desde el año 1946 he hecho periódicamente diferentes experiencias en el campo del objeto; pero, nunca con una finalidad total y expresiva de mi obra

${ }^{23}$ Juan Gich. Los cuarenta años de Modesto Cuixart. Tele eXpres, viernes 15 de abril de 1966

${ }^{24}$ Angel Marsa. Entre el ensueño y la clínica. El Correo Catalán. 1 de mayo de 1966.

${ }^{25}$ Carlos Carrero. Así es la gente. Modesto Cuixart, que ha rehusado la invitación de honor, cursada por la Bienal de Venecia, expone en «René Metras», su última producción. 


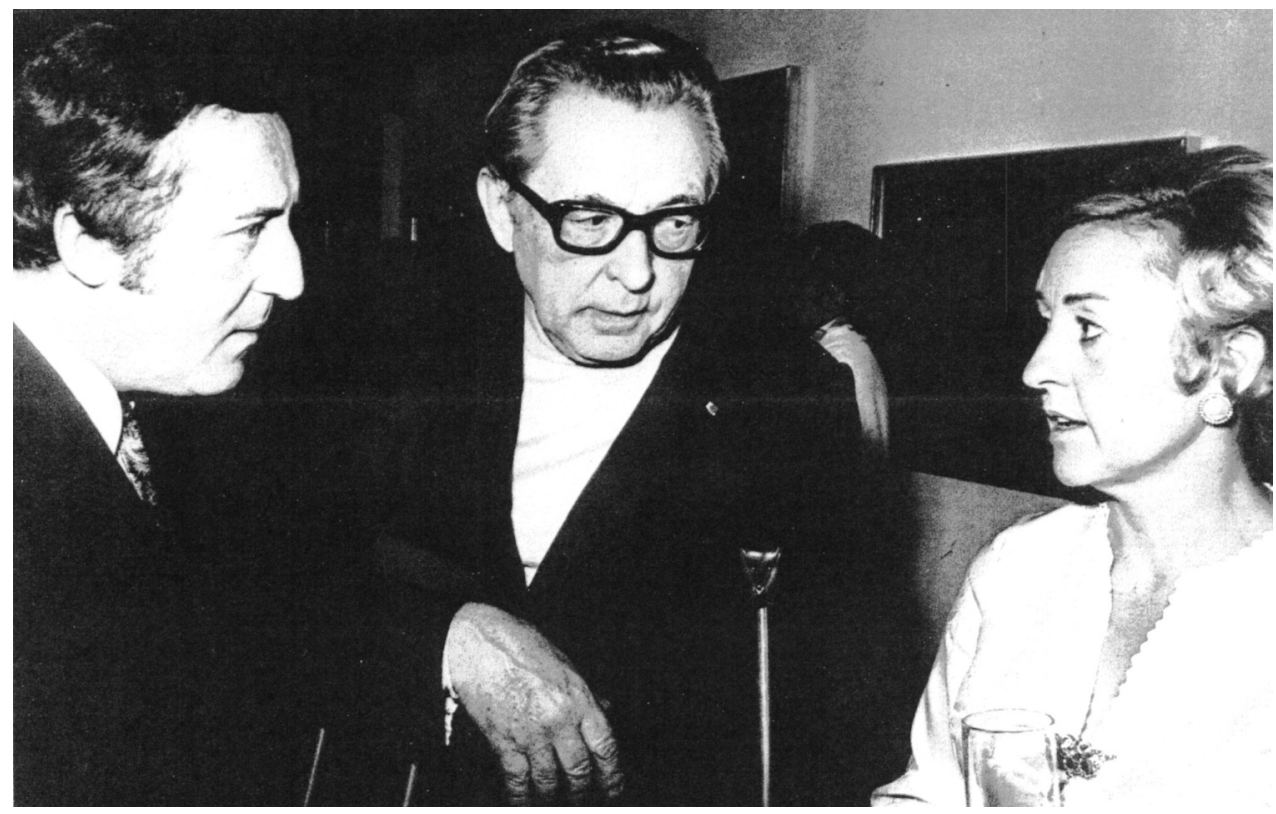

Fig. 7 En el centro Hartung junto al matrimonio Metras.

(...) «Modesto Cuixart, Gran Premio Internacional de la V Bienal de Sao Paulo, tenía que haber sido la «vedette» de la Bienal de Venecia, a la que tenía que asistir como invitado de honor.

- ¿Por qué ha rehusado la invitación?

- En esencia, para poner de manifiesto de una forma clara y rotunda que la libertad de acción y realización de un artista tiene que ser exhaustiva.

Coacciones, no»

Exposición de Hans Hartung en 1965. Hartung era uno de los creadores de la abstracción más original y complejo. En 1956 había sido Premio Guggenheim y en 1960 había recibido el Gran Premio de la Bienal de Venecia. El artista era rotundo al responder las preguntas del crítico Rafael Santos-Torroella ${ }^{26}$ y nadie mejor que él para explicar su pintura: «Los trazos gruesos expresan energía; los delgados, fragilidad, otros son líneas y otros, en fin, puntos de color... densidad, armonía, ligereza o espontaneidad. No es útil reunir a las imágenes; antes al contrario, para que la forma adquiera todo su valor expresivo es menester que se vea libre de servidumbres figurativas; que hable a través de sus formas al margen del tema»

${ }^{26}$ J.F.Yvars.René Metras. Reconstruir los sueños. Ambit Servicios Editoriales 2008 


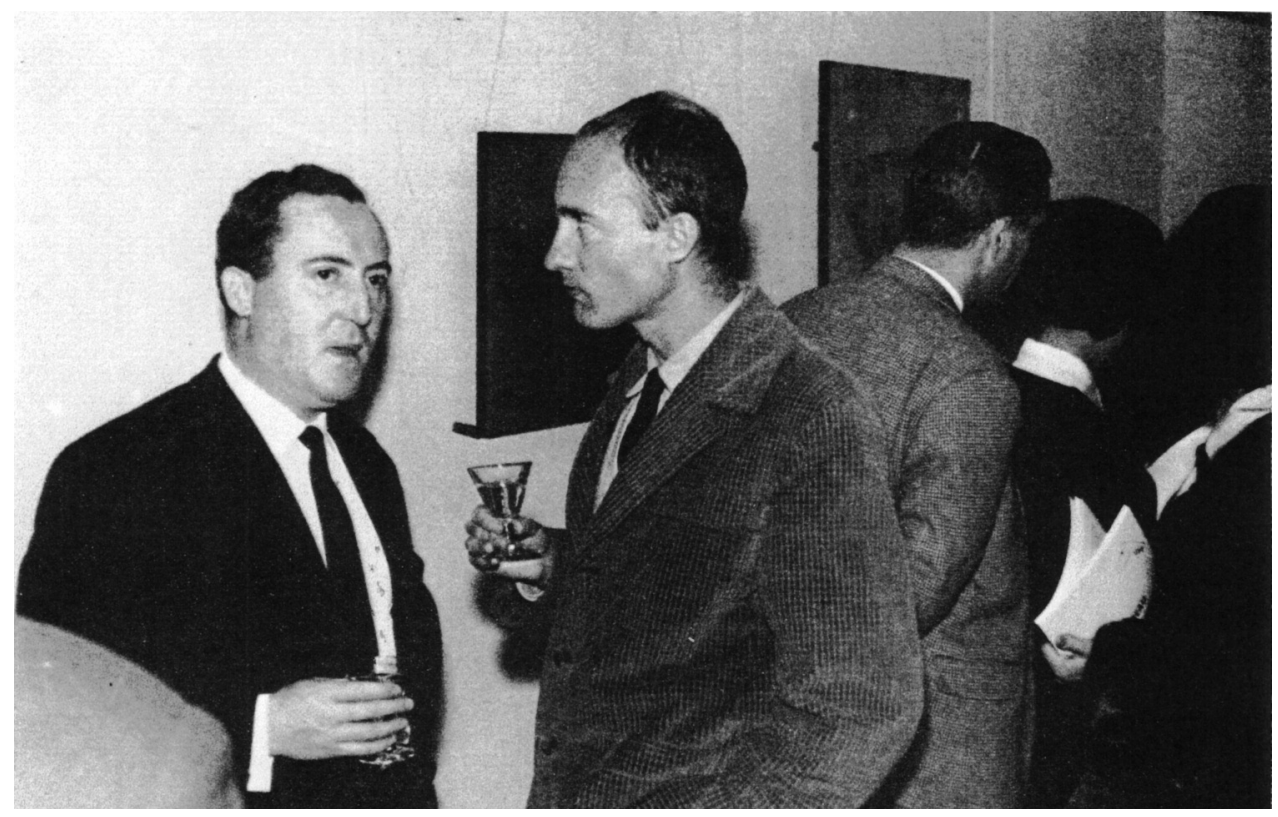

Figura 8: A la izquierda René Metras, conversando con Manolo Millares.

Exposición de Manolo Miralles del 9 de marzo a 12 abril 1966. Miralles llegó a la Galería en plena polémica en torno a una nueva pintura de formas rotundas sobre la desnuda superficie del lienzo. Millares colgaba en los muros arpilleras saturadas de color. El artista era ya una figura mítica, fundador del grupo el Paso en $1957^{27}$ y anteriormente lo había sido con el grupo Adlan ${ }^{28}$. Fue una muestra de impacto que atacaba el preciosismo decorativo en el que se debatía el Informalismo, buscando la realidad, descarnada e informe que el creador debe saber convertir en arte.

Las exposiciones de Hans Hartung y Manolo Millares sirven para captar en su significado plural los proyectos artísticos de la Galería René Metras, concluyendo el ciclo expositivo de «Presencias de nuestro tiempo» y recupera, de este modo, formas enraizadas en la vanguardia hispánica, que ampliaría en la década de los

${ }^{27}$ El paso es un colectivo de artistas que se fundó en febrero de 1957 en Madrid, siendo el grupo de mayor relevancia en la configuración y definición de la vanguardia española de posguerra. Los integrantes de El Paso en el momento de la firma del manifiesto y en sus primeras exposiciones como colectivo fueron los pintores Rafael Canogar, Luis Feito, Juana Francés, Manolo Millares, Manuel Rivera, Antonio Suárez, Antonio Saura y el escultor Pablo Serrano. Junto a estos artistas formaron parte del grupo los críticos de arte José Ayllón y Manolo Conde. En el año 1958 se incorporan los artistas Martín Chirino y Manuel Viola.En marzo de 1957 se publicó el manifiesto de El Paso redactado por José Ayllón y con el símbolo del grupo realizado por Antonio Saura basándose en una obra de Pablo Serrano.

${ }^{28}$ El grupo ADLAN (Amics de l'Art Nou, «amigos del arte nuevo») fue un movimiento artístico catalán fundado en Barcelona en 1932 por Joan Prats, Josep Lluís Sert y Joaquim Gomis, con el objetivo de promover el arte de vanguardia. 
setenta sus perspectivas hacia la poesía de la imagen y las expectativas surrealistas.

En Mayo de 1968 la Galería Metras, realizó una exposición antológica de Max Ernst. artista que depuraba cuidadosamente la vanguardia histórica al servicio de una imaginación desbordada. Insatisfecho con la abstracción informal busca una forma de expresión. El arte es sólo fantasía, parecen decir sus obras, tras sus atmósferas etéreas. Como dijo Santos Torroella ${ }^{29}$ : «Un conjunto de treinta obras señalan en la galería René Metras, la insólita presencia entre nosotros de ésta que es una de las figuras caudales de la vieja guardia surrealista...» (...) «Insólita, esto es desacostumbrada, porque nunca se tuvo ocasión en Barcelona, ni en los momentos en que, hace treinta o cuarenta años, el meridiano surrealista parecía estar dispuesto a pasar por ella, de contemplar aquí una exposición suya...». O, como diría Daniel Giralt Miracle ${ }^{30}$ : «Una exposición de Max Ernst es de por sí un acontecimiento en cualquier ciudad del mundo. Tanto más cuanto que ésta es la primera vez que se da y es de carácter antológico, como la que estos días podemos contemplar en las Galerías René Metras de nuestra ciudad...»

El 3 de enero de 1969 expone Salvador Dalí. Éste pondría el contrapunto surrealista. Un Dalí, mundano y desmedido en la presentación de treinta y cuatro aguafuertes: ocho Venus, ocho retratos de pintores célebres, temas mitológicos, temas surrealistas. Una sorpresa fue el aguafuerte coloreado a mano de la serie Apollinaire, que pudo verse por primera vez en la sala. Juan Gich ${ }^{31}$ nos dice al hablar de esta exposición: «No sé como se las arregla, pero, de una forma u otra Dalí siempre es tema de actualidad»

El 11 abril de 1969 expone Antonio Saura32aguafuertes, litografías, serigrafías y diversos grabados y dibujos en la Sala René Metras. La inauguración, como no podía ser de otra manera, se hace eco en la prensa escrita de Barcelona. Santos Torroella ${ }^{33}$, en su Dietario artístico dice: (...) «... Antonio Saura se decidiera a exponer entre nosotros. Ya era hora, porque el nombre de «el pintor expresionista español más representativo de nuestra generación (J.Ayllón) hacia demasiado tiempo que no sonaba aquí sino como algo parecido al testimonio de un ausencia»; Juan Cortés ${ }^{34}$, desde «La Vanguardia Española escribe:» Presenta «Galería René Metras» un extenso ejemplario de la obra gráfica de Antonio Saura, cuya muestra es la primera que del famoso internacional oscense se realiza en nuestra ciu-

\footnotetext{
${ }^{29}$ Santos Torroella. Dietario Artístico: Max Ernst, el manipulador. El Noticiero Universal, miércoles, 15 de mayo de 1968

${ }^{30}$ Daniel Giralt Miracle. Max Ernst o la fecundidad mental. Destino, Barcelona, 1 de junio de 1968

${ }^{31}$ Juan Gich.Grabados de Dalí. Los viernes Arte. Tele eXpres. 1969.

${ }^{32}$ Funda el grupo El Paso que dirigirá hasta la fecha de su disolución, en 1960, que venia a ser el contrapunto del Dau al Set barcelonés y tuvo unos efectos arrolladores en la evolución de la plástica peninsular.

${ }^{33}$ Satos Torroella. Dietario artístico. Antonio Saura. El Noticiero Universal, miércoles, 16 de abril de 1969.

${ }^{34}$ Juan Cortés. Saura. La Vanguardia Española, domingo, 4 de mayo de 1969.
} 
dad...» y desde Solidaridad Nacional, Rafael Manzano ${ }^{35}$ : Saura en las Galerías René Metras. «En la Sala René Metras expone Antonio Saura una vasta obra: «Aguafuertes» (pertenecientes a la serie «Novisaurias», editadas por «La Cometa», de Gustavo Gili; «litografías» (de la serie «Gigantes amorosas) y serigrafías (diversario, en color)...»

La galería René Metras durante los años 60 y 70 realizará exposiciones individuales, las de: J.B.Chereau, Luis Feito, Román Vallés, Will Faber, Wols, Hans Arp, Eusebio Sempere, Joan Ponç, Vasarely, Erwin Bechtold, Miquel Capel, Artigau, Norman Narotzky, Deswarte, Luis Gordillo, Lucio Fontana, Alberto Porta (Zush) y Josep Guinovart.; pasando del Informalismo a Saura, de Wols al Equipo Crónica.

Las muestras individuales de estos artistas se compaginaban con otras colectivas.

El 27 de agosto de 1965 se expondrá en la galería, «lbiza- 65, en la que se presentan 20 pintores representando a 12 países y que hacía un mes había sido expuesta en la galería Ivan Spence de Ibiza. Pascual Maisterra ${ }^{36}$, preguntando a René Metras y Carl van der Voort ${ }^{37}$ (...) «-Lo único que les une es pues su vinculación a Ibiza?. -Exactamente. No se trata de ningún grupo ni de ninguna escuela; son individualidades totalmente independientes y, como verás, sus maneras y técnicas expresivas son totalmente independientes. Desde Africa del Sur a Canadá, pasando por Suiza y los Estados Unidos, Asia incluida, participan en esta exposición. En total, doce países. - De España, ¿quiénes?. - Tres pintores bien distintos; Antonio Saura, primer premio Guggenheim-Carnegie, Manolo H, Mompó, Premio Nacional de Pintura en el Retiro de Madrid, y el ibicenco Rafael Tur Costa, de quien sin duda no tardará en hablarse mucho y bien. -¿Alguna mujer?. -Una que es también la más joven de los artistas que en esta exposición se presentan, Marianne Hermann, una alemana de estilo muy personal que espero que interese mucho aquí...» Tampoco pasará desapercibida esta exposición al humorista JIP38 de la que se hace eco en su viñeta humorística.

El 21 de septiembre de 1966 dentro de «Presencias 66» y patrocinada por Philip Morris International, se celebrará la exposición Marlboro. 11 artistas Pop: Una nueva imagen, en las que se ponen obras de D'Arcangelo, Jime Dim, Allen Jones, Gerad Laing, Wesley, Lichenstein, Peter Phillips, Rosenquist, Mel Ramon y Warhol.

Exposición 1972 - 1973.Con motivo del $7^{\circ}$ aniversario de la galería y en su apartado ART 7 BASEL - Presencias de Nuestro Tiempo - se expone obra de:

\footnotetext{
${ }^{35}$ Rafael Manzano. Saura en las Galerías René Metras. Solidaridad nacional, miércoles, 16 de abril de 1969

${ }^{36}$ Pascual Maisterra. Los pintores del mundo se dan cita en Ibiza. Tele eXpres, viernes, 27 de agosto de 1965.

${ }^{37}$ Director y manager de la galería Ivan Spence

${ }^{38}$ Ibiza 65 «Chez» Metras. Destino, Barcelona, 4 de septiembre de 1965. № 1465.
} 


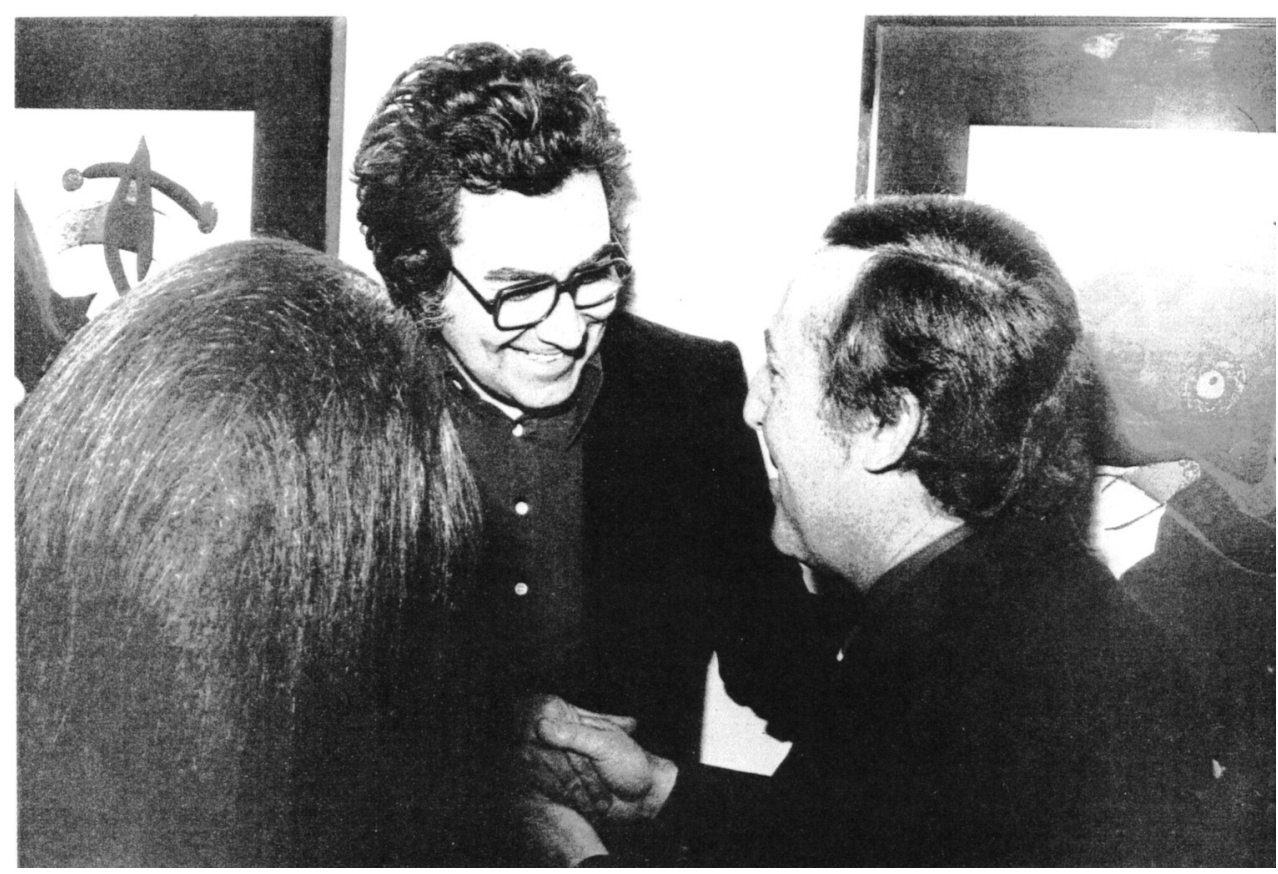

Figura 9: Un sonriente Antoni Tapies da la mano a René Metras a la derecha de la foto.

Cuixart, Fautrier, Fontana, Hartung, Paul Klee, Magritte, Max Ernst, Miró, Picasso, Ponç, Tapies, Wols, entre otros. Repasando la trayectoria de René Metras y Antoni Tapies, sorprende el olvido del artista en su «Memoria personal, fragmento para una autobiografía» del que fuera amigo y entusiasta seguidor desde sus comienzos, adquiriendo alguna de sus obras tempranas, al que no menciona ni una sola vez.

Exposición 1972-1973. Con el nombre de «Simbolismo mágico» (en lo que parece un retorno a la atmósfera de Dau al Set) en la pintura catalana, destacan las veladuras de Cuixart, el universo singular y nocturno de Joan Ponç y las ensoñaciones de Massanet .

Habrá otras muchas exposiciones entre las que destacamos: «Du vie a l'inmateriel», mostrando obras de Degotex, Dupuy, Janicot, Yves Klein, Mathieu/Michaux de Galí, Freíd, Porta y «Syn» con obras de Bechtold, Berner, Dienst, Jürgen Ficher. Todas ellas fueron un referente para los jóvenes artistas que visitaban la Metras convencidos de encontrar en sus salas un referente para su propia obra.

Pero sin duda alguna, la exposición que dio la medida de la dimensión artística de René Metras, fue el homenaje ofrecido a Joan Miró, en 1964 coordinadas al unísono por las tres galerías de la calle Consejo de Ciento, Sala Gaspar, Belarte y Galería René Metras al convertir el espacio artístico barcelonés en un nuevo es- 


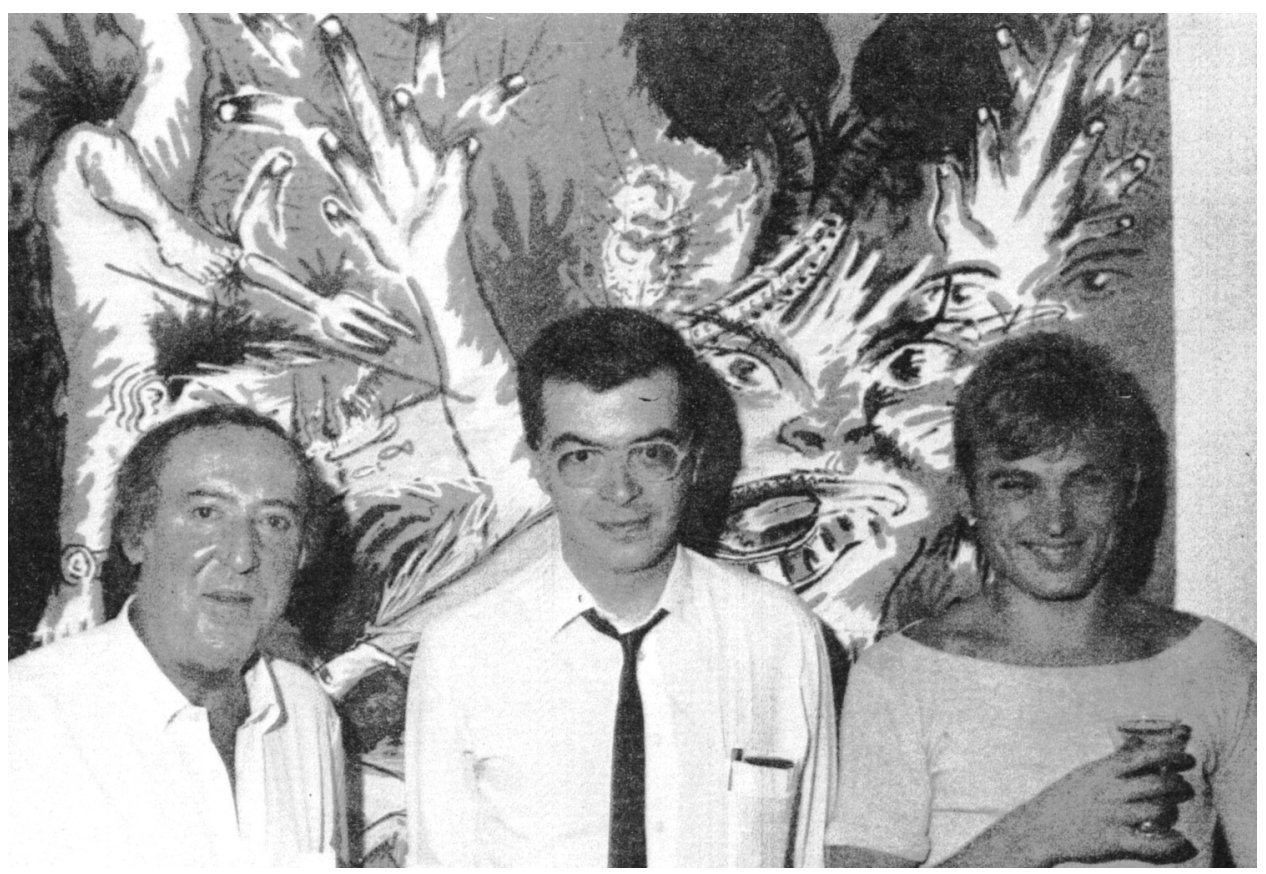

Fig 10: René Metras a la izquierda, en el centro El Hortelano y a nuestra derecha un jovencísimo Miquel Barceló.

pacio vertebrador del arte contemporáneo, celebrando la última producción del gran artista que tuvo más de ceremonia de iniciación y gesto mágico de conjuro a los viejos augurios que amenazaban el arte nuevo.

Era diciembre y el gesto se entendía como un inesperado y adelantado regalo de Reyes. La muestra fue debidamente «observada» por las fuerzas vivas y debidamente manipulada por la censura de la época porque tuvo una incidencia limitada en el reducido mundo del arte barcelonés, pero sirvió de reivindicación de la obra de un mago, clandestino todavía. No sorprende que a la acerada pluma del periodista Del Arco $^{39}$ Miró no tuviera inconveniente en afirmar: «Yo me expreso plásticamente, intento ir mucho más allá que el puro lenguaje de las formas y colores. ¿Qué es eso que todavía llamamos arte? Una aportación humana más; «...por mi parte he dejado caer mi semilla en el terreno arte» «...espero que germine». Como colofón irrepetible se editaron once litografías mironianas con participación de los textos de críticos y creadores de renombre como Cirlot, Cirici, Foix, Brossa, Gasch, Perucho y Santos-Torroella, entre otros.

\footnotetext{
${ }^{39}$ René Metras. 1926-1984.Reconstruir los sueños J.F. Yvars. Ambit Servicios Editoriales 2008
} 


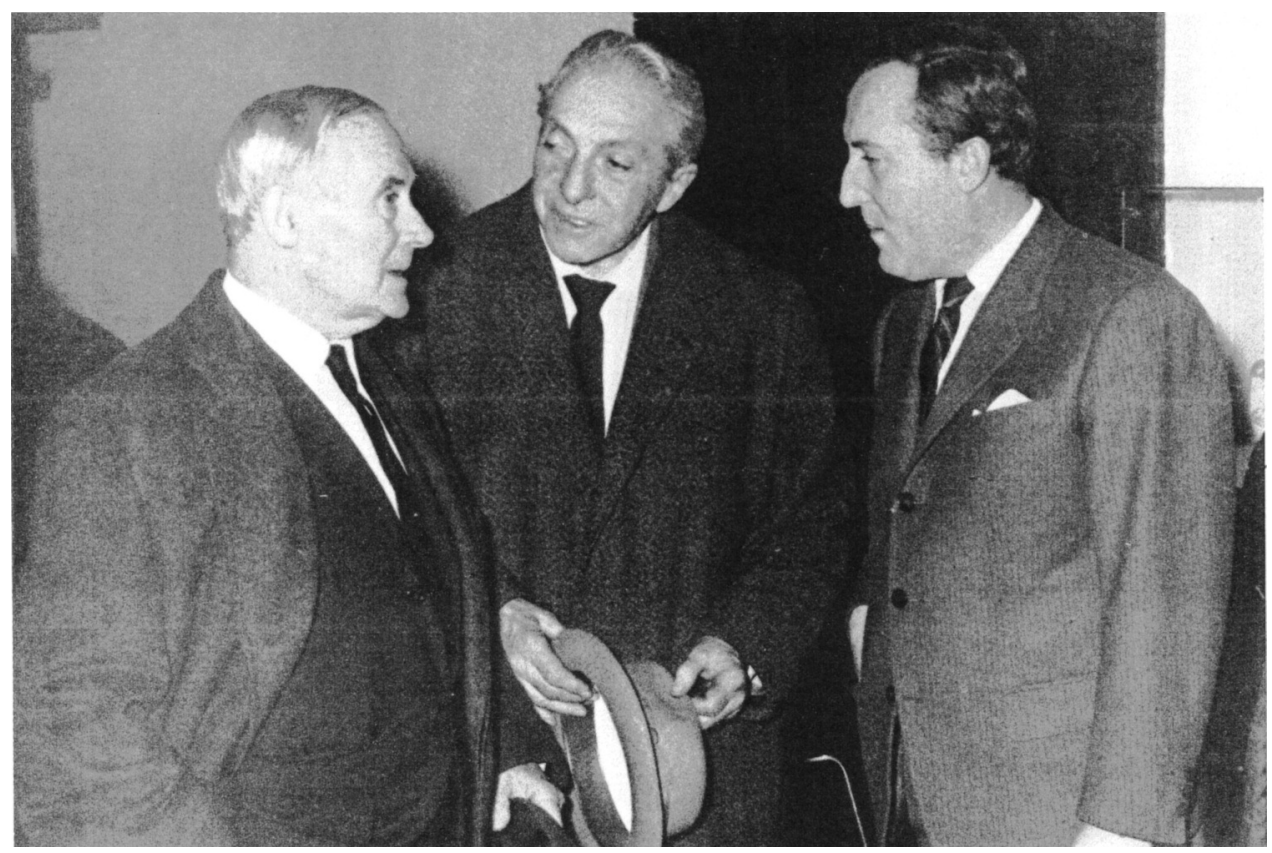

Fig.11: Joan Miró a la izquierda de la foto conversa con Joan Prats, en el centro y René Metras a la derecha, ambos muy atentos a las palabras de Miró.

Pero volviendo al hombre, al René Metras apasionado del arte, al joven francés que se gustaba llamar catalán, que siguió luchando, fiel a su originaria actividad de promotor cultural de difusión del arte, como demuestra su colaboración en Dau al Set, El Correo de las Artes, y en el Club 49, desde el cual apoyó, dentro de sus muchas iniciativas, sumándose con otros intelectuales a solicitar a las autoridades barcelonesas la creación del Museo de Arte Contemporáneo de Barcelona, como una institución viva que patrocinara toda clase de actividades y constituyera un fondo permanente y progresivo de obras de arte y que acabó, ante la imposibilidad de convencer a las autoridades de la ciudad, y bajo la figura de una sociedad anónima utilizando la Cúpula del Coliseum, para celebrar exposiciones y albergar las obras donadas por diversos artistas como fondo para este fin. Por ello sorprende que a pesar de llevar toda una vida luchando desde el ámbito cultural barcelonés y su total integración en la misma, no haya sido reconocida suficientemente su labor y echamos en falta el nombre de René Metras en obras y publicaciones ${ }^{40}$ junto a todos esos intelectuales, artistas y galeristas que han llenado tantas páginas en los últimos años sobre la iniciación del arte de posguerra en España en general y, en

\footnotetext{
${ }^{40}$ Cesáreo Rodríguez-Aguilera. Arte moderno en Cataluña. Examen de qué cosa sea arte y qué cosa modernidad. 1986. Editorial Planeta. Mención somera de Metras.

- Vicente Aguilera Cerni. Iniciación al arte español de postguerra. Noviembre 1970. Edicions 62.
} 


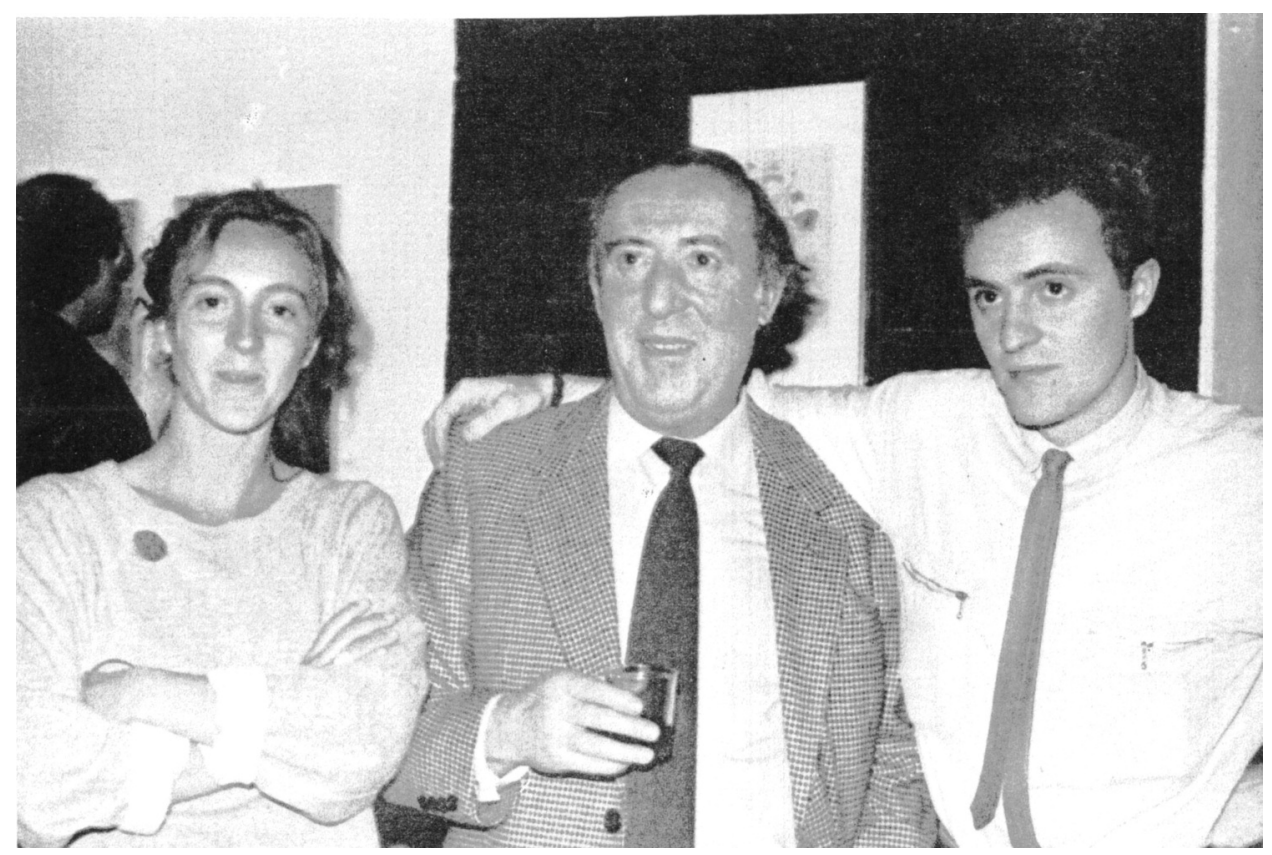

Fig. 12: René Metras feliz, en el centro, flanqueado por sus hijos Margaret y Charles.

Cataluña, en particular. Pero recordando las palabras de María Teresa, en mayo de 2008:

«El olvido, ese viejo remedio

de la miseria humana.

Hay playas donde el mar

Continúa naciendo»

René Metrás falleció en Barcelona el 23 de mayo de 1984 pero un hombre nunca muere cuando su obra, la mejor realizada en su vida, sus hijos, continúa la labor por él emprendida.

Sólo queda remarcar que el ejemplo de la Galería René Metras es un caso paradigmático en la historia de las galerías de arte de la ciudad de Barcelona pues fue y sigue siendo un referente del arte de vanguardia, y al que los hijos de René Metras, Margaret y Charles, actuales directores de la misma, dedican sus esfuerzos en aras a conservar el legado de sus padres y el espíritu con el que su padre la creó. 
